\title{
Apresentação Dossiê Educação Ambiental
}

\begin{abstract}
- Para que as palavras durem dizendo cada vez coisas distintas, para que uma eternidade sem consolo abra o intervalo entre cada um de seus passos, para que o devir do que éo mesmo seja, em sua volta a começar, de uma riqueza infinita, para que o porvir seja lido como o que nunca foi escrito...há que se dar as palavras.
\end{abstract}

Jorge Larrosa

A arte do mosaico foi minha inspiração para convidar pesquisadores e pesquisadoras de Educação Ambiental para apresentarem textos que são resultado de suas pesquisas. A ideia é apostar na diferença, seja ela teórica, metodológica ou política.

Um balanço desta primeira década do século XXI aponta a necessidade de reiterarmos nosso compromisso ético e político com o tema meio ambiente. Ouso dizer que ainda carregamos esse grande desafio, principalmente, voltado à educação.

Imbuído dessa vontade de trazer leituras diversas, olhares caleidoscópicos sobre diferentes temas e abordagens da Educação Ambiental é que o mosaico foi construído e a partir do qual pretendo anunciar intencionando que as palavras que compõem os textos durem até dizerem coisas distintas, diferentes e que movimentem outros pensamentos que permitam que inventemos outras pesquisas que possibilitem escrevermos outros textos, com outra duração das palavras.

Para a montagem do mosaico-dossiê, recorri a pesquisadores e pesquisadoras que há algumas décadas têm contribuído significativamente com abordagem teórica sobre a Educação Ambiental. Busquei diversificar e convidei também outro grupo - uma "nova geração" - que tem mostrado muito fôlego para uma gama de pensamento/invenções/criações/imaginações dos temas ambientais.

O texto que abre o dossiê propõe que pesquisadores em Educação Ambiental se identifiquem com os compromissos com a vida. Luiz Marcelo de Carvalho propõe indagar sobre as possíveis relações entre nossos "atos" de investigação e nossos compromissos éticos e, para isto, convida-nos a dialogar com o pensamento de Bakhtin e por alguns outros autores, leitores seus ou não, envolvendo tais questões. 
Em seguida, o texto de Mauro Guimarães procura refletir sobre a experiência instituinte de formação de rede de educadores ambientais como forma de consolidar a perspectiva crítica da educação ambiental na escola e na sociedade. Seu argumento, apoiado na militância da vertente de uma Educação Ambiental crítica mostra que "a construção de uma sociedade sustentável passa pela desconstrução do paradigma da disjunção, do $1+1$, para a construção do $1 \mathrm{com} 1$, em uma abordagem relacional que percebe e atua sobre a complexidade da realidade socioambiental". Desse modo, as "Redes se apresentam como um novo campo de atuação da sociedade organizada, que assumida no seu caráter inovador, pode e deve se constituir num ambiente de formação propício a essa perspectiva educacional".

Os quatro artigos seguintes tratam de currículo e prática pedagógicas, envolvendo diferentes sujeitos, espaços e níveis de escolaridade. O texto de autoria de Mirian Jonis Silva, Sandra Escovedo Selles e Rui Marques Vieira, nos leva ao universo da Educação de Jovens e Adultos (EJA). O artigo aborda a Educação Ambiental travada em proposta curricular construída coletivamente de modo a articular a abordagem de questões sociais no ensino de Biologia às especificidades da EJA. Ainda com a abordagem curricular, o quarto texto, de Jacqueline Girão e Carlos Frederico Loureiro, busca uma reflexão ainda polêmica no campo da Educação Ambiental quando aborda a disciplinaridade/ integração. Para tecer seus argumentos, os autores buscam a experiência disciplinar ocorrida no município de Armação de Búzios (RJ) e mostram que esse debate é profícuo, perturbador e, por isso, necessário. O artigo de Guilherme Pereira, Fernando Guerra, Lana Fonseca e Bruno Cintra apresenta o trabalho desenvolvido com professores da educação básica da cidade de Itaguaí/RJ, para se pensar a Educação Ambiental a partir de oficinas com a finalidade de identificar representações ambientais e inferir o reflexo das representações observadas sobre a compreensão-ação desse grupo e suas práticas pedagógicas. Finalizando este bloco, Ludmila Cavalcante e Ana July Lins enfrentam o embate que tem sido posto ao currículo do curso de Pedagogia: a necessária discussão ambiental.

$\mathrm{Na}$ fronteira da discussão, intercalando as pedras do mosaico, o artigo de Juliana Merçon mostra uma experiência fora do contexto escolar/universitário, ocorrido na cidade de Morelia, Michoacán, México. Trata-se de uma pesquisa cujo objetivo era analisar as atividades de um projeto de educação ambiental comunitária em um espaço não formal.

Currículo e práticas pedagógicas insistem em continuar ou pertencer no/ao mosaico, porém, o último bloco é composto por artigos de pesquisadores que têm buscado inspirações nos Estudos Culturais e na vertente pós-estruturalista para pensar a Educação Ambiental. Marcelo Giraldi de Castro e Antonio Carlos Amorim lançam/produzem olhares para um conjunto de práticas de representação que produzem especificidades e diferenças à escola rural. Os autores buscaram uma "diversidade de sentidos específicos que, ao ser movimentada, procurou apresentar múltiplas 
possibilidades de representação que circulam na confluência de uma escola rural em Piracicaba (SP)". O texto de Marta Catunda e Marcos Reigota envolve o cotidiano de práticas escolares urbanas e rurais e analisam a paisagem sonora, incluindo gravações sonoras, em vídeo, e registro de decibéis entre outras atividades expressivas e musicais. Oficinas de fotografias deslocam o ambiente no artigo proposto por Leandro Belinaso e Ana Preve. Longe de tentar explicar, os autores querem anunciar um movimento de escrita que dispara "o encontro de experiências em educação ambiental que tenham como princípio o enfraquecimento das imagens-clichês, a despoluição do nosso invisível e uma escrita afetada pelas forças do indizível”. "Navegar é preciso. Viver não é preciso". Davi Codes e Marco Barzano se lançam em uma comunidade ribeirinha na cidade de São Francisco do Conde/BA e apresentam um texto em que, a partir dos enunciados dos pescadores, buscam compreender a paisagem ambiental daquele lugar, a partir das conexões entre o passado e o presente daqueles sujeitos. Encerrando o dossiê, Shaula Sampaio e Maria Lúcia Wortmann apresentam análises de textos publicados em jornais e revistas brasileiros, abordando alguns dos significados sobre a Amazônia que participam ativamente dos modos como essa região vem sendo inventada na contemporaneidade.

Vida, práticas pedagógicas e curriculares, professores, pescadores, escolas, som, imagem, comunidades tradicionais, Rio, Bahia, Amazônia, México, redes. Recomendo que a leitura deste dossiê se inicie no artigo em que as palavras-chave ou títulos, pequenas pedras desse mosaico, impulsionem à curiosidade, ao pensamento que prolifera, que permite ideias diferentes. Leitores e leitoras, vejam que os termos que iniciam esse parágrafo são os mesmos, conhecidos por nós há várias décadas. Mas não são os mesmos! Os autores deste dossiê pensam de outro modo e apostam em suas diferentes perspectivas teórico-metodológicas. Por isso, dão outro sentido àquilo que podemos considerar igual e, desse modo, contribuem para pensarmos e considerarmos que uma outra Educação Ambiental é possível. (...) Há que se dar as palavras.

Marco Barzano 